\title{
Optimization of Processing parameters on Low Temperature Plasma Nitriding of AISI 420 Martensitic Stainless Steel
}

\author{
Insup Lee ${ }^{1}$ \\ ${ }^{1}$ Dongeui University \\ Department of Advanced Materials Engineering, Dongeui University 47340, Busan, Republic of Korea \\ islee@deu.ac.kr
}

\begin{abstract}
Low temperature plasma nitriding was performed in order to study the effect of processing parameters like processing temperature, treatment time, nitrogen and carbon content on the expanded martensite layer ( $\alpha_{\mathrm{N}}^{\prime}$ layer) of the AISI 420 martensitic stainless steel. Plasma nitriding was carried out and various times from 4 to $15 \mathrm{~h}$, with changing the nitrogen content from $10 \%$ to $35 \%$ and carbon content from $0 \%$ to $6 \%$ at fixed temperature of $400^{\circ} \mathrm{C}$. The surface hardness and $\alpha_{N}^{\prime}$ layer thickness values increases with increasing processing time and increasing the nitrogen content. Contrary, these values decreases with increasing the methane content.The highest surface hardness (around $1330 \mathrm{HV}_{0.1}$ ) and highest $\alpha_{\mathrm{N}}^{\prime}$ layer thickness (around $33 \mu \mathrm{m}$ ) were achieved when treated with $25 \%$ nitrogen content for $15 \mathrm{~h}$. Although, this longer processing time exhibits poor corrosion resistance. The corrosion resistance decreases with increasing methane content. Best corrosion resistance is achieved when treated with $25 \%$ nitrogen content for 6 h, without any methane content.
\end{abstract}

Keywords: AISI 420 martensitic stainless steel, $\alpha_{\mathrm{N}}^{\prime}$ layer, Corrosion resistance, Low temperature plasma nitriding.

\section{Introduction}

Stainless steel are well known for its excellent corrosion resistance and moderate hardness and wear resistance. That is the reason behind its popularity in different industrial purposes. However, most stainless steels have low hardness and therefore poor resistance to wear unless a surface modification treatment is applied. The martensitic grades of stainless steels are thus mainly used where hardness, strength, and wear resistance are required in the tools and automotive industry as well as in jewelry manufacturing, food storage and weaponry. AISI 420 martensitic stainless steel is a high chromium mold steel and has a martensitic microstructure. Having reasonable corrosion resistance, shock resistance and high plasticity, AISI 420 martensitic stainless steel has been widely used in manufacturing turbine blades and valve parts. Nevertheless, its industrial applications are limited due to low hardness and poor wear resistance [1]. The improvement of these surface properties can be done by thermochemical process like low temperature plasma assisted nitriding. Studies shows that in austenitic stainless steel, improved surface can be achieved due to the formation of S-phase (expanded austenite phase) [2]. Meanwhile in martensitic stainless steel the formed layer is called $\alpha_{N}^{\prime}$ layer (expanded martensite layer), as reported by Kim et al. [3], which helps to improve the surface hardness and wear resistance. If processing parameters are chosen optomizely, obtaining a treated surface having higher hardness and corrosion resistance than the untreated surface, is possible. However, if the process parameters are not correctly selected, the treated surface can present a corrosion resistance lower than that expected for the bulk material after adequate solution treatment, which must be strongly avoided particularly on the case of stainless steels. In the present work, investigations are done on the surface modifications by plasma nitriding on AISI 420 martensitic stainless steel to observe the effect of different processing time, the effect of various $\mathrm{N}_{2}$ content and the effect of carbon by introducing methane gas in the nitriding environment.

\section{Experimental Procedure}

Circular coupons of solution treated AISI 420 martensitic stainless steel of $16 \mathrm{~mm}$ diameter and $3 \mathrm{~mm}$ thickness were prepared for the treatment. It is generally known that the solution treatment was done at $1050^{\circ} \mathrm{C}$ for 30 mins/inch and then quenched in water. The composition of AISI 420 martensitic stainless steel is given in the Table I. The solution treated samples are denoted as "bare" in this paper. The surfaces of the circular coupons were mirror polished by means of automatic polishing machine and then cleaned before starting the plasma treatment. Then, the samples were placed on the cathode table 
in the plasma ion nitriding system. The next step is pre-sputtering operation. Plasma chamber has to evacuate below 50 mTorr before starting this operation. During this operation $\mathrm{Ar}$ and $\mathrm{H}_{2}$ ion sputtering was performed for at least 40 minutes for further surface cleaning. After sputtering, plasma nitriding process was immediately carried out at $400^{\circ} \mathrm{C}$ temperature for various time ( $4 \mathrm{~h}$ to $15 \mathrm{hr}$ ), with changing $\mathrm{N}_{2}$ percentage $(10 \%-35 \%)$ and with introducing various amount of $\mathrm{CH}_{4}(0 \%$ to $6 \%$ ) in the glow discharge environment in a gas mixture of $\mathrm{N}_{2}$ and $\mathrm{H}_{2}$ and at 4.0 Torr vacuum pressure and 400V discharge voltage. According to L. Mariano et. al. [4], at higher temperature $\left(>450^{\circ} \mathrm{C}\right)$ the surface hardness of AISI 420 martensitic stainless steel decreases. So, the temperature was chosen as $400^{\circ} \mathrm{C}$, according to their results.

Table 1: Chemical compositions (wt.\%) of AISI 420 martensitic stainless steel.

\begin{tabular}{|l|l|l|l|l|l|l|l|l|l|l|}
\hline Materials & $\mathrm{Fe}$ & $\mathrm{C}$ & $\mathrm{Si}$ & $\mathrm{Mn}$ & $\mathrm{P}$ & $\mathrm{S}$ & $\mathrm{Ni}$ & $\mathrm{Cr}$ & $\mathrm{Mo}$ & $\mathrm{Cu}$ \\
\hline AISI 420 & Bal. & 0.286 & 0.404 & 0.719 & 0.0266 & 0.0036 & 0.231 & 13.484 & 0.093 & 0.123 \\
\hline
\end{tabular}

After treatment, the samples were cooled in the vacuum chamber up to the room temperature. The plasma nitrided samples were sectioned for metallographic examination and surface hardness determination. The samples were cut, mounted, polished and finally the cross-sectional surfaces were etched with Vilella's reagent $(1 \mathrm{~g}$ picric acid $+100 \mathrm{ml}$ Ethyl alcohol + $5 \mathrm{ml} \mathrm{HCl}$ ). The microstructures of the surface of all the samples were observed by using an Olympus BX51M optical microscope. A Rigaku D/Max-200 X-ray diffractometer was employed to analyze different phases formed on the treated surfaces by using $\mathrm{Cu}-\mathrm{K}_{\alpha}$ radiation $(\lambda=1.544 \AA$ ). Micro hardness measurements were carried out with the digital Micro Vickers hardness tester Matsuzawa MMT-X7B using an indentation load of $0.49 \mathrm{~N}(50 \mathrm{~g})$ and a loading time 10 seconds. Glow discharge optical emission spectrometry (GDOES) analysis of the treated samples was also performed to analyze the distribution of nitrogen and carbon in the crystal lattice. A potentiodynamic polarization technique was applied to estimate the corrosion characteristics of the plasma nitrocarburized layer in a 3.5\% NaCl solution by using Princeton Applied Research VersaSTAT 3 potentiostat. For reference electrode $3.5 \% \mathrm{KCl} \mathrm{Ag} / \mathrm{AgCl}$ was selected and platinum $(\mathrm{Pt}$ ) was used for the counter electrode. The anodic polarization curves were recorded with a sweep speed of $1 \mathrm{mV} / \mathrm{sec}$. Higher corrosion potential $\left(\mathrm{E}_{\text {corr }}\right)$ and lower current density $\left(i_{\text {corr }}\right)$ indicate higher corrosion resistance.

\section{Results and Discussion}

\subsection{Effect of Processing Time}

Figure 1 (a) shows the XRD patterns of AISI 420 martensitic stainless steel samples nitrided at $400^{\circ} \mathrm{C}$ and with $25 \%$ nitrogen content for various processing time starts from $4 \mathrm{~h}$ to $15 \mathrm{~h}$. Figure 1(a) shows that the untreated sample (bare) produced two diffraction peaks of $\alpha^{\prime}(110)$ and $\alpha^{\prime}(200)$ in the range of 20-80 ${ }^{\circ}$. Figure 1(a) also indicates that, the surface of the nitrided samples mainly consists of $\alpha_{\mathrm{N}}^{\prime}$ and $\varepsilon-\mathrm{Fe}_{2-3} \mathrm{~N}$. The $2 \theta$ values of $\alpha_{\mathrm{N}}^{\prime}$ peak and $\varepsilon-\mathrm{Fe}_{2-3} \mathrm{~N}$ peak are very close to each other, they even overlapped to each other in some patterns. As $\alpha_{N}^{\prime}$ layer is formed due to the solid solution of nitrogen, it expanded the lattice planer spacing of $\alpha^{\prime}(110)$ and shifted the (110) peak of $\alpha^{\prime}$ toward a lower diffraction angle in the XRD pattern. According to Bragg's law, lower $2 \theta$ angle indicates the increase in d-spacing of crystal planes i.e. increase the volume of unit cell. Thus, this shift of $2 \theta$ angle confirms the formation of the $\alpha_{\mathrm{N}}^{\prime}$ layer as suggested by Kim et al. [4]. Moreover, the presence of $\mathrm{Cr}_{2} \mathrm{~N}$ peaks on $8 \mathrm{~h}, 10 \mathrm{~h}$ and $15 \mathrm{~h}$ treated samples indicates the poor corrosion behavior. These chromium nitrides form dark spots on the $\alpha_{N}^{\prime}$ layer which can be seen in Figure 2(b \& c). Also the sharpness of all the peaks increases with increasing processing time up to $6 \mathrm{~h}$. But the intensity of all the peaks become weaker and blunter with increasing processing time from $8 \mathrm{~h}$ to $15 \mathrm{~h}$. It is the evidence that the nitrogen supersaturated martensite forms a stable condition for $6 \mathrm{~h}$ treatment. From this phenomena, it can be assumed that, increasing the processing time for more than $6 \mathrm{~h}$, forces the supersaturated-nitrogen to come out of the martensite matrix and forms chromium nitride which decreases the corrosion resistance. GDOES analysis are manifested in Figure 1(b). Nitrogen occupies deeper region from the surface with increasing the processing time. Longer processing time, gives nitrogen enough time and energy to diffuse through the surface to cover more depth. Due to high concentration gradient in the surface, longer processing time increases the diffusion depth of nitrogen and hence increase the thickness of nitrogen-supersaturated martensite $\left(\alpha_{\mathrm{N}}^{\prime}\right)$ layer. Comparing the GDOES data with the microstructure (from Figure 2), it can be verified that the depth covered by nitrogen represents the thickness of $\alpha_{\mathrm{N}}^{\prime}$ layer. Moreover, it can be seen from the GDOES analysis that carbon in the matrix is substituted by nitrogen in the $\alpha_{\mathrm{N}}^{\prime}$ layer region, which decreases the carbon content (wt $\%$ ) values near the surface. And the values are 
restored to their original base value just below the end point of $\alpha_{N}^{\prime}$ layer. Figure 2 shows the cross section micrographs of the AISI 420 martensitic stainless steel samples, nitrided at $400^{\circ} \mathrm{C}$ for 4,8 and $15 \mathrm{~h}$. From the figure, it can be shown that the $\alpha_{N}^{\prime}$ layer thickness increases with increasing processing time. It is also clear from the Figure 2 that the dark spots, visible in the $\alpha_{N}^{\prime}$ layer, increases with increasing processing time from $8 \mathrm{~h}$ to $15 \mathrm{~h}$. These dark spots are the formation of chromium nitrides, which are detrimental for the corrosion behavior of the samples. The changes of surface hardness and $\alpha_{N}^{\prime}$ layer thickness with increasing processing time are shown in Figure 3(a). The $\alpha_{\mathrm{N}}^{\prime}$ layer thickness increases from around $16 \mu \mathrm{m}$ to $33 \mu \mathrm{m}$, when processing time was increased from $4 \mathrm{~h}$ to $15 \mathrm{~h}$. The surface hardness values are almost same (around $1300 \mathrm{HV}_{0.1}$ ) for all these samples, which is almost four times higher than the surface hardness of bare sample (around $358 \mathrm{HV}_{0.1}$ ). The anodic polarization curves of the untreated (bare) and treated samples with various processing time, in 3.5\% $\mathrm{NaCl}$ aqueous solution, are shown in Figure 3(b). There is no passivation region in the bare sample. In addition, the current density increased at a high rate immediately after the corrosion potential exceeds $60 \mathrm{mV}$. This rapid increase in current density during polarization test of stainless steel is known to be caused by the breakdown of the passive film on the surface, followed by localized corrosion. The corrosion behavior improves initially with increasing processing time from $4 \mathrm{~h}$ to $8 \mathrm{~h}$. The corrosion potential $\left(E_{\text {corr }}\right)$ was changed from $-147 \mathrm{mV}$ for the bare sample to around $-178 \mathrm{mV}, 60$ $\mathrm{mV}$ and $-110 \mathrm{mV}$ respectively for the $4 \mathrm{~h}, 6 \mathrm{~h}$ and $8 \mathrm{~h}$ nitrided sample, even though there is no passivation region. Also the current densities of those nitrided samples were quite same, suggesting that the corrosion rate of the samples are almost same as the untreated one. On the other hand beyond $8 \mathrm{~h}$ treatment, increasing processing time decreases the corrosion resistance of the treated samples. $E_{\text {corr }}$ value was decreased to about $-246 \mathrm{mV}$ and $-270 \mathrm{mV}$ respectively for the $10 \mathrm{~h}$ and $15 \mathrm{~h}$ treated sample which is much lower than the bare one. In addition, corrosion current densities of this two samples are one to two orders of magnitude higher than that of bare sample, indicating the faster corrosion rate of these samples. This happens certainly for the presence of $\mathrm{Cr}_{2} \mathrm{~N}$ in the $\alpha_{\mathrm{N}}^{\prime}$ layer, which was confirmed by XRD in Figure 1(a).

\subsection{Effect of Nitrogen percentage}

The XRD patterns of AISI 420 martensitic stainless steel samples nitrided at $400^{\circ} \mathrm{C}$ for $6 \mathrm{~h}$ with changing the nitrogen percentage from $10 \%$ to $35 \%$ are depicted in Figure 4(a). It also indicates that, the surface of the nitrided samples consists of mainly $\alpha_{\mathrm{N}}^{\prime}$ and $\varepsilon-\mathrm{Fe}_{2-3} \mathrm{~N}$. The intensity of all the peaks are sharpest in $25 \% \mathrm{~N}_{2}$ treated sample. And at $35 \% \mathrm{~N}_{2}$ treated sample, the presence of $\mathrm{Cr}_{2} \mathrm{~N}$ peak denotes that the corrosion resistance of this sample is poor. The broadening of all the peaks of $35 \% \mathrm{~N}_{2}$ treated sample indicates that some strain was built up due to overly supersaturated-nitrogen on the martensite matrix, which helps to the formation of chromium nitride as chromium has a strong affinity to nitrogen. Also the blunt and weak intensity of all the peaks indicate the occurrence of severe crystal deformation due to the presence of enough amount of supersaturated-nitrogen, which cause to increase the $\alpha_{\mathrm{N}}^{\prime}$ layer. Therefore, further increase of nitrogen percentage will promote the formation of chromium nitride.

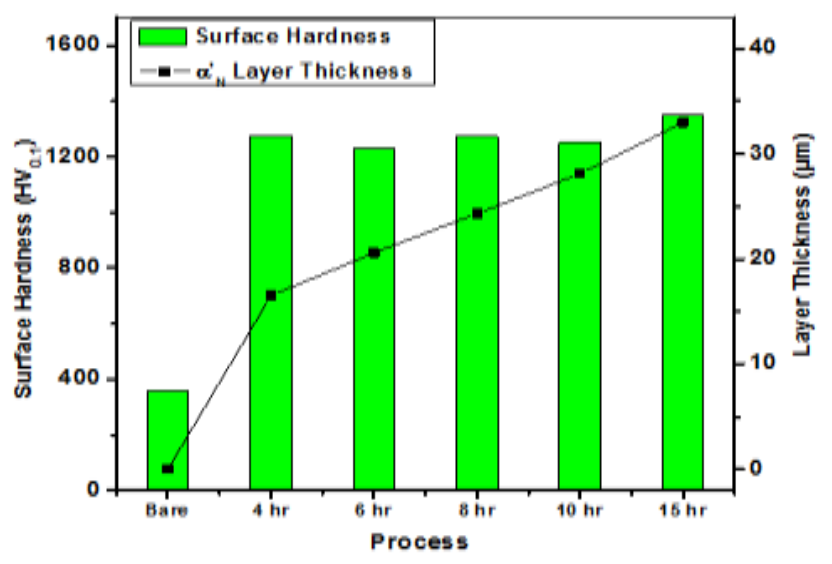

(a) Surface hardness and $\alpha_{N}^{\prime}$ layer thickness

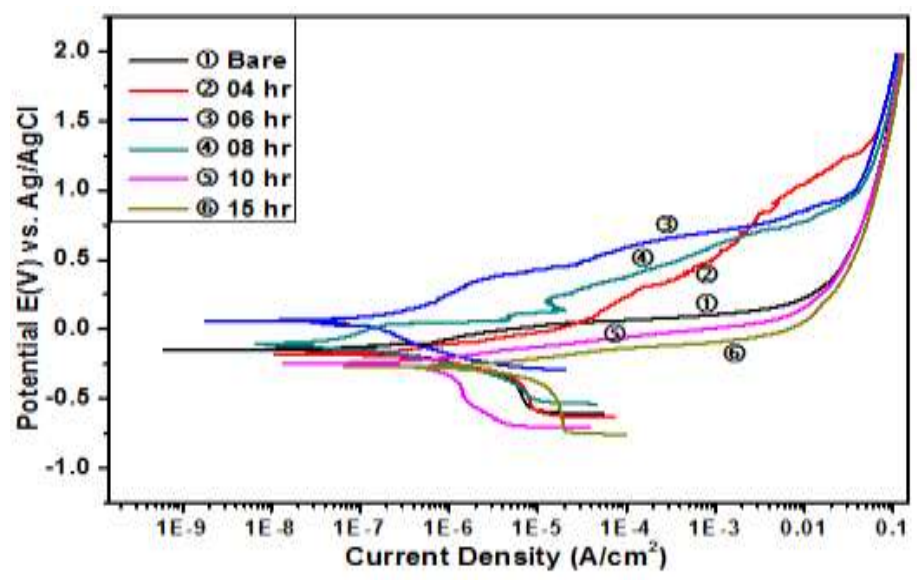

(b) Anodic Potentiodynamic Polarization curves

Fig. 1: AISI 420 samples for various processing time at $400^{\circ} \mathrm{C}$ with $25 \% \mathrm{~N} 2$. 


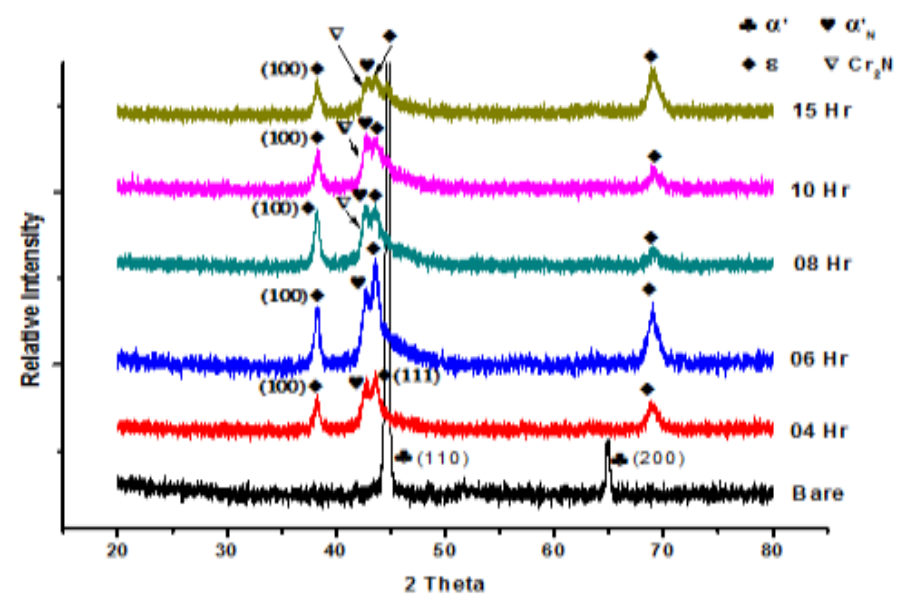

(a) XRD patterns

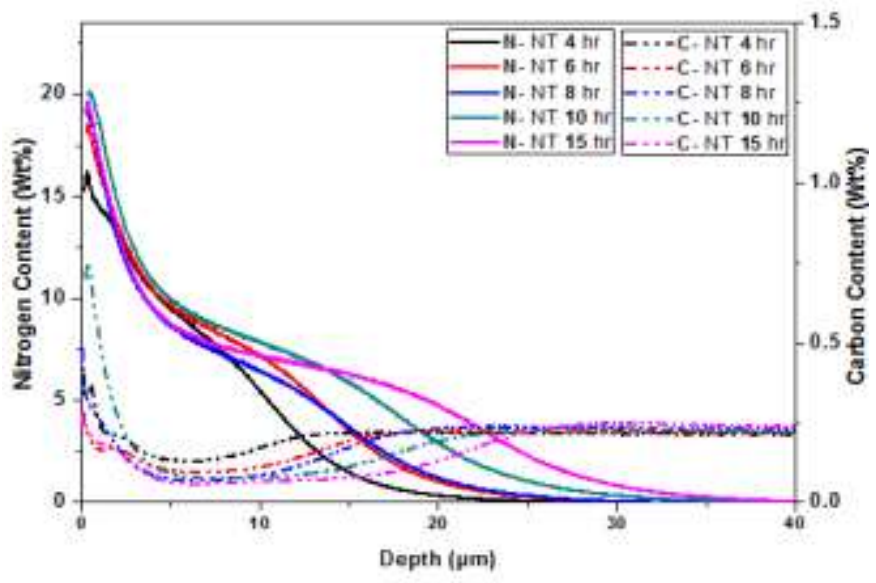

(b): GDOES

Fig. 2: Optical micrographs of AISI 420 samples for various processing time at $400^{\circ} \mathrm{C}$ with $25 \% \mathrm{~N}_{2}$.

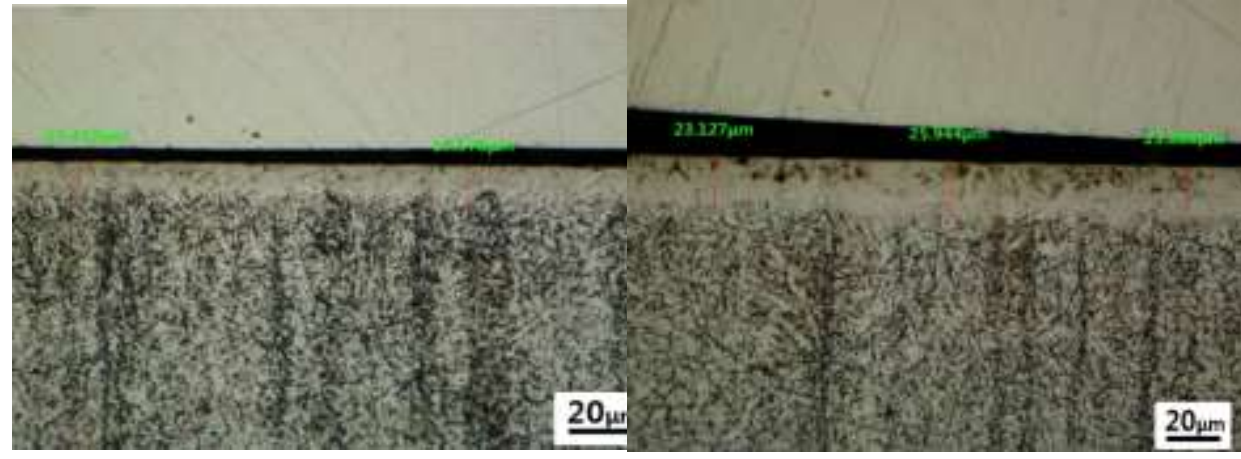

(a) $4 \mathrm{hr}$

(b) $8 \mathrm{hr}$

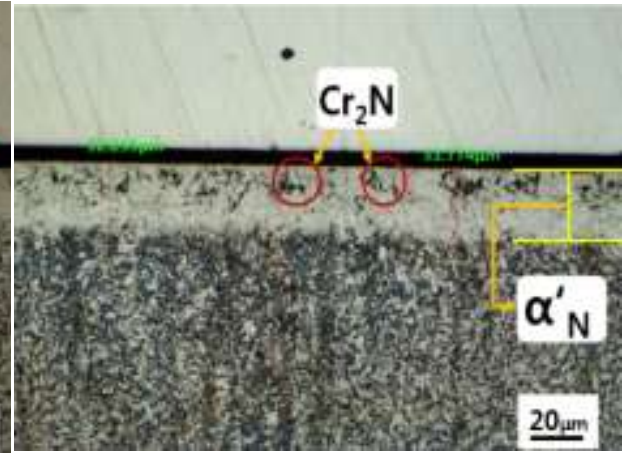

(c) $15 \mathrm{hr}$

Fig. 3: AISI 420 samples for various processing time at $400^{\circ} \mathrm{C}$ with $25 \% \mathrm{~N}_{2}$.

GDOES analysis exhibited in Figure 4(b), sample surface indicate the presence of higher nitrogen content (wt $\%$ ), when nitrogen percentage in the nitriding chamber was increased from $10 \%$ to $30 \%$. Thus higher concentration gradient of nitrogen enhance the diffusion depth of nitrogen through martensite matrix and aids the increment of $\alpha_{N}^{\prime}$ layer thickness. Also, nitrogen goes deeper into the sample from the surface at $30 \% \mathrm{~N}_{2}$ treated sample. That means, nitrogen diffuses deeper into the bulk when nitrided with higher amount of nitrogen gas, with fixing the other parameters. The $\alpha^{\prime}$ layer thickness increases with increasing nitrogen percentage (Figure 5). In the microstructure, the $\alpha_{\mathrm{N}}^{\prime}$ layer of $6 \mathrm{~h}$ treated samples is comparatively cleaner than the $15 \mathrm{~h}$ treated sample, which means they have less $\mathrm{Cr}_{2} \mathrm{~N}$ than the $15 \mathrm{~h}$ treated sample, in the $\alpha_{\mathrm{N}}^{\prime}$ layer. However, the maximum thickness does not increase more than $22 \mu \mathrm{m}$ where that is $33 \mu \mathrm{m}$ for $15 \mathrm{~h}$ treated one. The surface hardness and $\alpha_{N}^{\prime}$ layer thickness comparison shown in Figure 6(a) show that the $\alpha_{N}^{\prime}$ layer thickness increases with increasing amount of nitrogen, though their surface hardness remains almost same (around $1230 \mathrm{HV}_{0.1}$ ). The $\alpha_{N}^{\prime}$ layer thickness increases from about $16 \mu \mathrm{m}$ to $22 \mu \mathrm{m}$ when the nitrogen content increases from $10 \%$ to $35 \%$ respectively. Although their surface hardness values are quite constant, it has almost 4 times higher value than the bare one. The $\alpha_{N}^{\prime}$ layer thickness increases with increasing nitrogen percentage (Figure 5). In the microstructure, the $\alpha_{N}^{\prime}$ layer of $6 \mathrm{~h}$ treated samples is comparatively cleaner than the $15 \mathrm{~h}$ treated sample, which means they have less $\mathrm{Cr}_{2} \mathrm{~N}$ than the $15 \mathrm{~h}$ treated sample, in the $\alpha_{N}^{\prime}$ layer. However, the maximum thickness does not increase more than $22 \mu \mathrm{m}$ where that is $33 \mu \mathrm{m}$ for $15 \mathrm{~h}$ treated one. The surface hardness and $\alpha_{\mathrm{N}}^{\prime}$ layer thickness comparison shown in Figure 6(a) show that the $\alpha_{\mathrm{N}}^{\prime}$ layer thickness increases with increasing amount of nitrogen, though their surface hardness remains almost same (around 1230 $\left.\mathrm{HV}_{0.1}\right)$. The $\alpha_{\mathrm{N}}^{\prime}$ layer thickness increases from about $16 \mu \mathrm{m}$ to $22 \mu \mathrm{m}$ when the nitrogen content increases from $10 \%$ to 
$35 \%$ respectively. Although their surface hardness values are quite constant, it has almost 4 times higher value than the bare one. Figure 6 (b) represents the anodic potentiodynamic polarization curve of the AISI 420 samples treated with various nitrogen percentage. Introducing low amount of nitrogen has adverse effect on the corrosion resistance of AISI 420 nitrided samples. As can be seen from the polarization curve the $E_{\text {corr }}$ value decreased to about $-587 \mathrm{mV}$ for $10 \% \mathrm{~N}_{2}$ treated sample compared to that of bare (around $-147 \mathrm{mV}$ ). Also the current density of $10 \% \mathrm{~N}_{2}$ treated sample increased to one order of magnitude, indicating higher corrosion rate. But more increase of nitrogen percentage shows the increase of corrosion resistance. $E_{\text {corr }}$ value increased to about $60 \mathrm{mV}$ for $25 \% \mathrm{~N}_{2}$ treated sample, along with the decrease of current density closer to the bare sample. But there is no significant change in corrosion behavior for further increase of nitrogen percentage. $E_{c o r r}$ value of around $-220 \mathrm{mV}$ and $-258 \mathrm{mV}$ respectively of $30 \%$ and $35 \% \mathrm{~N}_{2}$ treated samples indicate nearly same corrosion resistance as the bare sample. Also their corrosion current density shows the same resemblance with the bare sample. Thus $25 \% \mathrm{~N}_{2}$ treated sample shows the best corrosion resistance among all the nitrided sample.

\subsection{Effect of $\mathrm{CH}_{4}$ Percentage}

Figure 7(a) depicts the XRD patterns of AISI 420 samples nitrided for $6 \mathrm{~h}$, at $400^{\circ} \mathrm{C}$ with fixed $25 \% \mathrm{~N}_{2}$ and increasing the amount of $\mathrm{CH}_{4}$ from $0 \%$ to $5 \%$. As the $\mathrm{CH}_{4}$ percentage increases, the $2 \theta$ values of $\alpha_{\mathrm{N}}^{\prime}$ peak increases and their peak intensity also becoming stronger. This phenomena indicates that, the nitrogen supersaturated-martensite lattice are recovering from their distorted form or a new layer is forming. As can be seen in $0 \%$ to $1 \% \mathrm{CH}_{4}$ treated sample, the $2 \theta$ values of $\alpha_{\mathrm{N}}^{\prime}$ peak increases to higher angle and peak intensity also increases. The microstructure (Figure 8) and the GDOES analysis (Figure 7 (b)) also point out the decrease of $\alpha_{\mathrm{N}}^{\prime}$ layer thickness with the increase of the amount of $\mathrm{CH}_{4}$. With further increment of $\mathrm{CH}_{4}$ percent to $3 \%$ and $5 \%, 2 \theta$ values of that peak moves to higher angle and its intensity also becomes stronger, which resembles with the $\alpha_{\mathrm{C}}^{\prime}$ peak. So, with increasing the amount of $\mathrm{CH}_{4}$ the possibility of forming $\alpha_{\mathrm{N}}^{\prime}$ layer decreases while the 


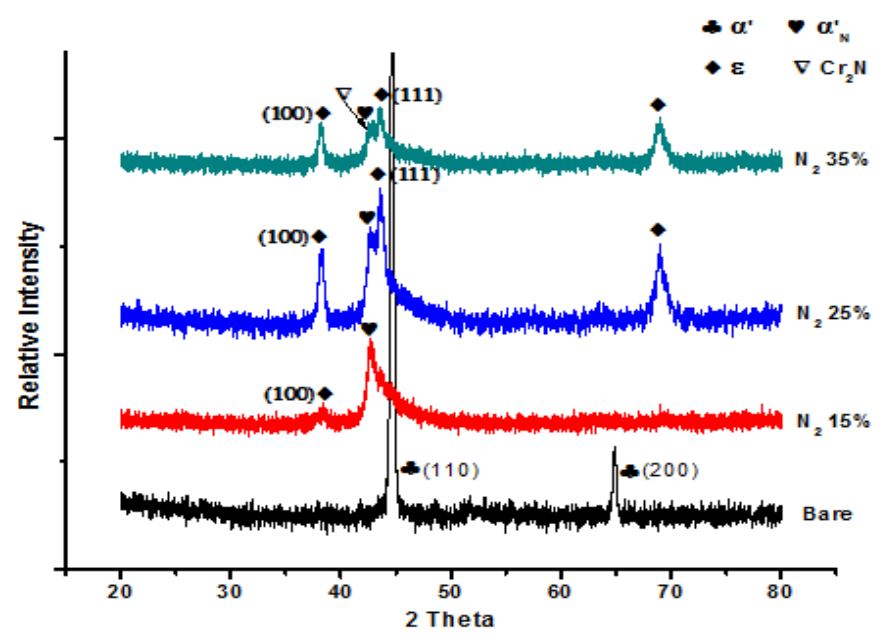

(a) XRD patterns

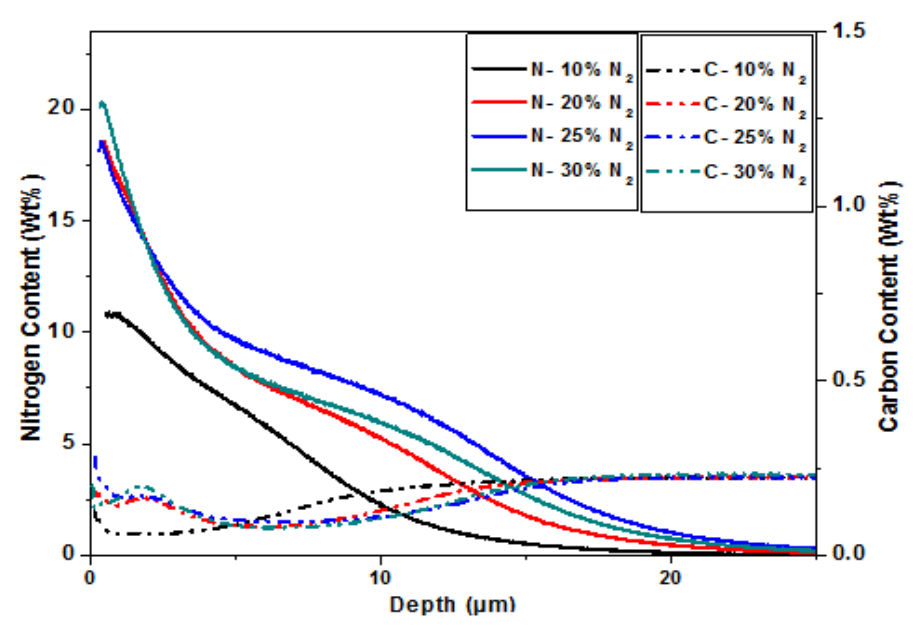

(b): GDOES

Fig. 4: AISI 420 samples for changing $\mathrm{N}_{2}$ percentage at $400^{\circ} \mathrm{C}$ for $6 \mathrm{~h}$.

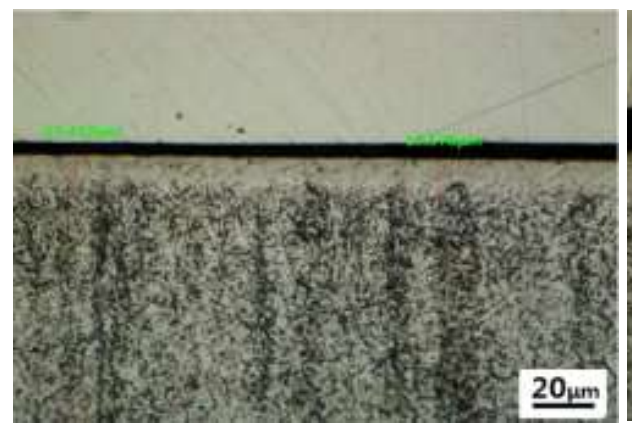

(a): $10 \% \mathrm{~N}_{2}$

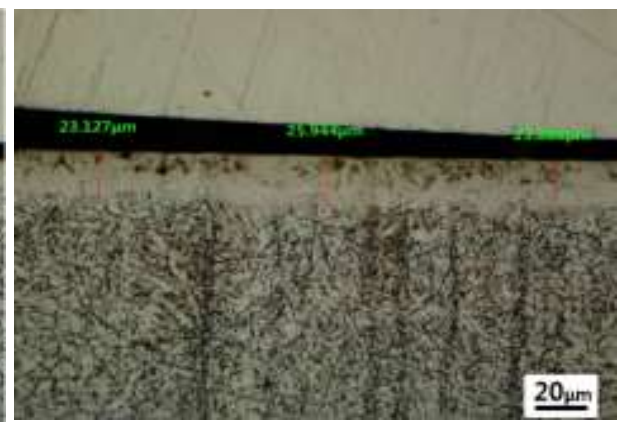

(b): $20 \% \mathrm{~N}_{2}$

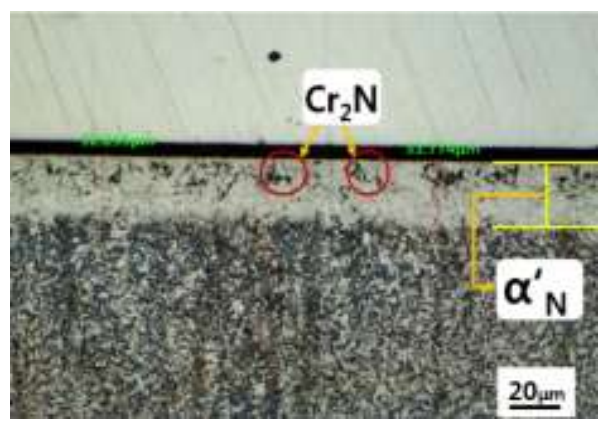

(c): $30 \% \mathrm{~N}_{2}$

Fig. 5: Optical micrographs of AISI 420 samples for Changing $\mathrm{N}_{2}$ percentage at $400^{\circ} \mathrm{C}$ for $6 \mathrm{~h}$.

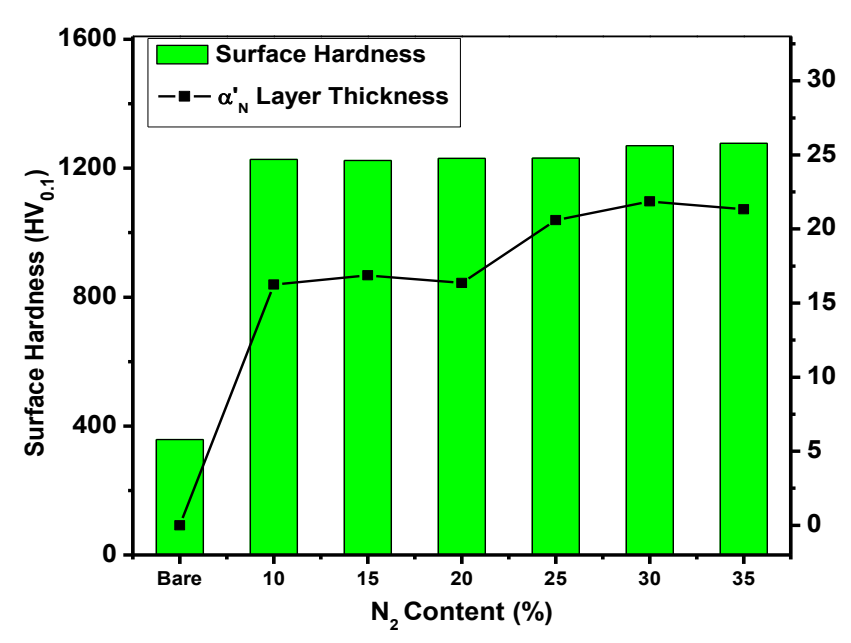

(a): Surface hardness and $\alpha_{N}^{\prime}$ layer thickness

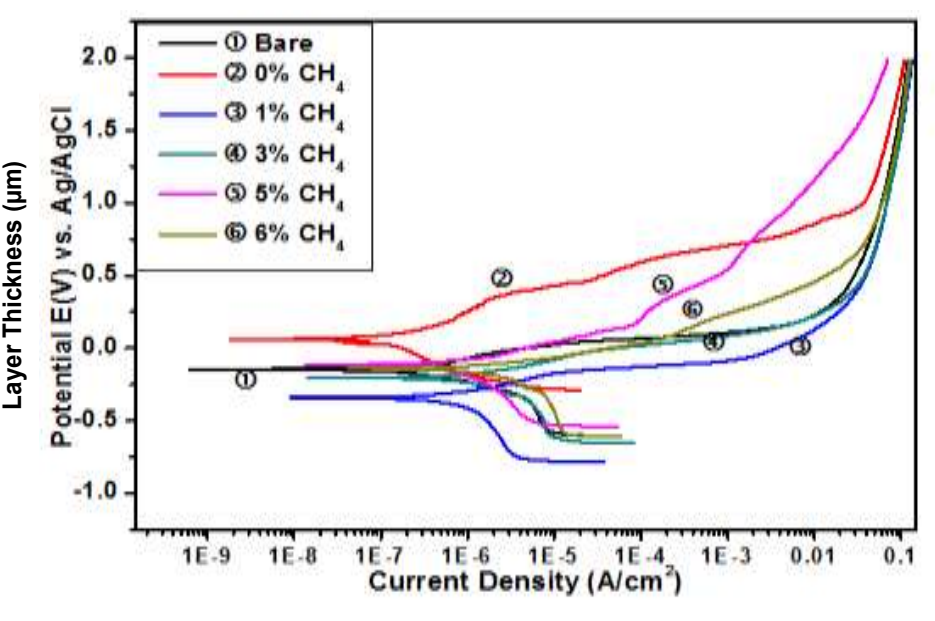

(b): Anodic Potentiodynamic Polarization curves

Fig. 6: AISI 420 samples for changing $\mathrm{N}_{2}$ percentage at $400^{\circ} \mathrm{C}$ for $6 \mathrm{~h}$. 


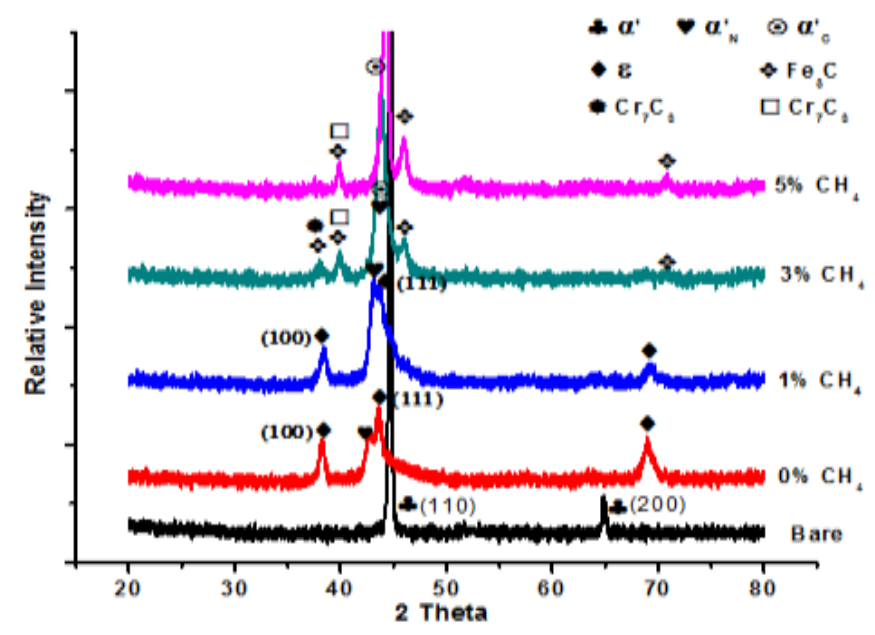

(a) XRD patterns

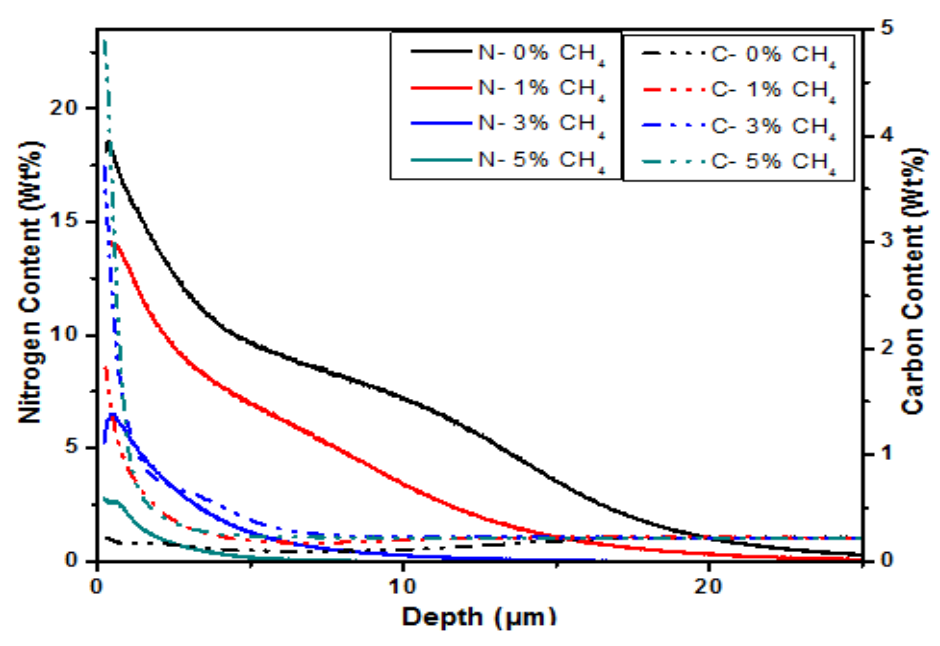

(b): GDOES

Fig. 7: AISI 420 samples for changing $\mathrm{CH}_{4}$ percentage with $25 \% \mathrm{~N}_{2}$ at $400^{\circ} \mathrm{C}$ for $6 \mathrm{~h}$.

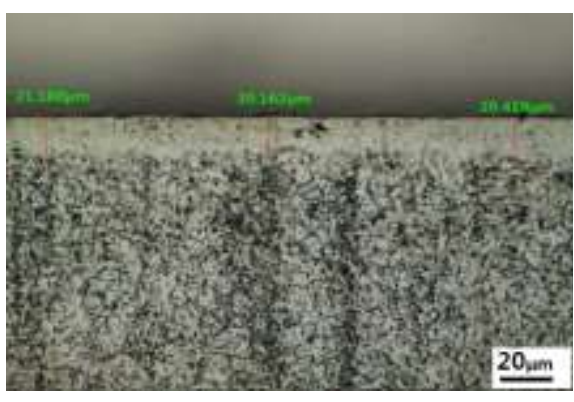

(a): $0 \% \mathrm{CH}_{4}$

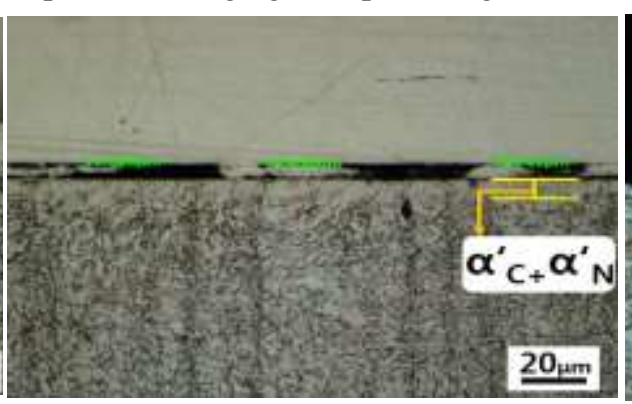

(b): $3 \% \mathrm{CH}_{4}$

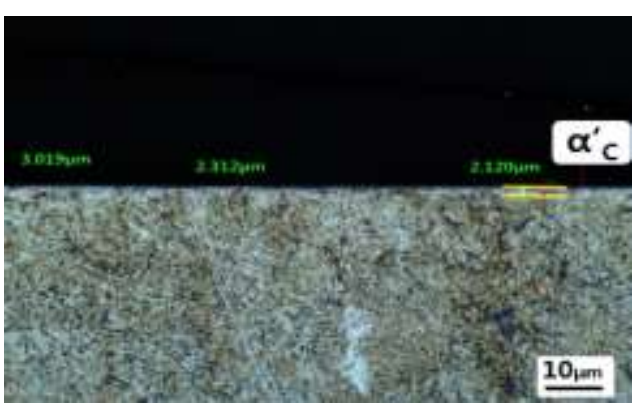

(c): $6 \% \mathrm{CH}_{4}$

Fig. 8: Optical micrographs of AISI 420 samples for changing $\mathrm{CH}_{4}$ percentage with $25 \% \mathrm{~N}_{2}$ at $400^{\circ} \mathrm{C}$ for $6 \mathrm{~h}$.

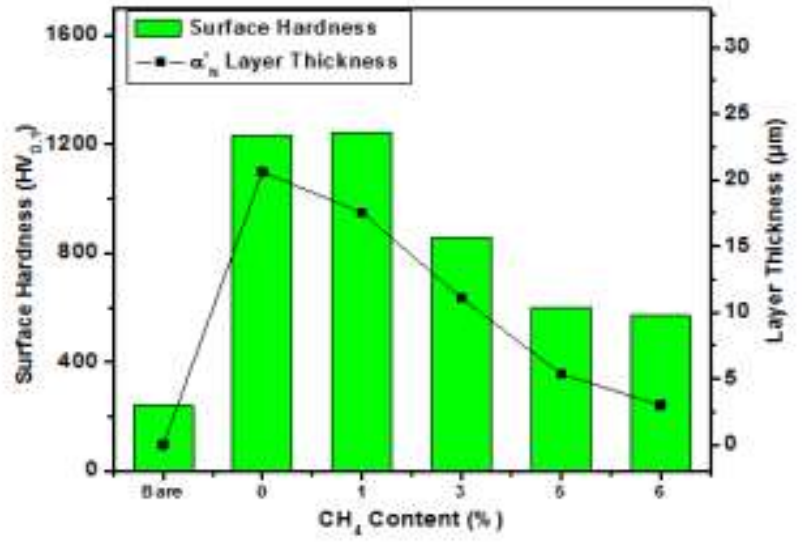

(a): Surface hardness and $\alpha_{N}^{\prime}$ layer thickness

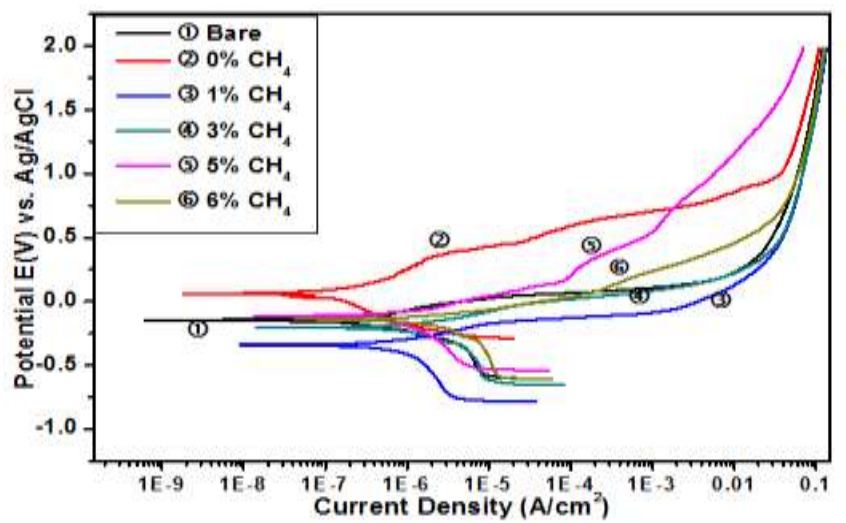

(b) Anodic Potentio dynamic Polarization curves

Fig. 9: AISI 420 samples for changing $\mathrm{CH}_{4}$ percentage with $25 \% \mathrm{~N}_{2}$ at $400^{\circ} \mathrm{C}$ for $6 \mathrm{~h}$. 
possibility of forming $\alpha_{C}^{\prime}$ layer increases. Also at higher $\mathrm{CH}_{4}$ percent, the presence of $\mathrm{Cr}_{23} \mathrm{C}_{6}, \mathrm{Cr}_{7} \mathrm{C}_{3}$ and $\mathrm{Fe}_{3} \mathrm{C}$ peak are found in the XRD analysis, which are very detrimental for their corrosion resistance.The cross sectional microstructures from Figure 8 show that the thickness of the $\alpha_{N}^{\prime}$ layer decreases with increasing the amount of $\mathrm{CH}_{4}$ percent. The $\alpha_{\mathrm{N}}^{\prime}$ layer have decreased so much in $6 \% \mathrm{CH}_{4}$ treated sample that it is very hard to identify the layer from the bulk matrix. And earlier in the XRD analysis (Figure 7(a)), the formation of $\alpha_{C}^{\prime}$ layer has been already confirmed for beyond $3 \% \mathrm{CH}_{4}$ treated samples. But the thickness of $\alpha_{C}^{\prime}$ layer cannot be measured accurately as it is inseparable from the $\alpha_{N}^{\prime}$ layer. Moreover, the differences of surface hardness and hardened layer thickness of all the $\mathrm{CH}_{4}$ treated samples are compared in Figure 9(a). The surface hardness and hardened layer thickness have decreased with the increasing value of $\mathrm{CH}_{4}$ percent. Surface hardness decreased from around $1230 \mathrm{HV}_{0.1}\left(0 \% \mathrm{CH}_{4}\right)$ to $620 \mathrm{HV}_{0.1}\left(6 \% \mathrm{CH}_{4}\right)$. And hardened layer thickness values have decreased from about $22 \mu \mathrm{m}\left(0 \% \mathrm{CH}_{4}\right)$ to $5 \mu \mathrm{m}\left(6 \% \mathrm{CH}_{4}\right)$, which is supported by the GDOES analysis (Figure 7(b)). The polarization curve of nitrided AISI 420 martensitic stainless steel with increasing amount of $\mathrm{CH}_{4}$ as represented in Figure 9(b). The $\mathrm{CH}_{4}$ treated samples shows poor corrosion resistance compared with that treated without $\mathrm{CH}_{4}$. The $E_{\text {corr }}$ value decreased to about -343 $\mathrm{mV}$ for $1 \% \mathrm{CH}_{4}$ treated sample which is much lower compared to $60 \mathrm{mV}$ of only nitrided $\left(0 \% \mathrm{CH}_{4}\right)$ sample. This value is even worse than the bare one $(-147 \mathrm{mV}) . E_{\text {corr }}$ value and corrosion current density of $3 \%, 5 \%$ and $6 \% \mathrm{CH}_{4}$ treated samples, indicate similar to worse corrosion behavior as the bare one. Thus, conclusions can be drawn that introduction of methane gas in nitriding atmosphere has no significant effect on the corrosion resistance of AISI 420 martensitic

\section{Conclusions}

1. The $\alpha_{N}^{\prime}$ layer thickness values increases very rapidly with increasing processing time, while surface hardness remains almost same. On the other hand the corrosion resistance increases up to $6 \mathrm{~h}$ treatment, after that the corrosion resistance becomes poorer.

2. With increasing nitrogen percentage $\alpha_{N}^{\prime}$ layer thickness values increases but not as much as increasing processing time, while surface hardness also remains same. Also their corrosion resistance values are as same as the bare one, except for the $25 \%$ treated one. It shows the best corrosion resistance among all the treated samples, even better than the bare one.

3. Introducing methane gas is not helpful for the nitrided samples. Increasing methane percentage, decreases the surface hardness and $\alpha_{N}^{\prime}$ layer thickness and also degrades their corrosion behavior.

\section{Acknowledgement}

This paper was supported by the Basic Research Program through the National Research Foundation of Korea funded by the Korean Ministry of Education (2017R1A2B1003729).

\section{References}

[1] I. Alphonsa, A. Chainani, P. M. Raole, B. Ganguli, P. I. John, "A study of martensitic stainless steel AISI 420 modified using plasma nitriding," Surf. Coatings Technol., vol. 150, pp. 263-268, 2002.

[2] C. Li, T. Bell, "Corrosion properties of active screen plasma nitrided 316 austenitic stainless steel," Corros. Sci., vol. 46, pp. 1527-1547, 2004.

[3] S. Kim, J. Yoo, J. Priest, M. Fewell, "Characteristics of martensitic stainless steel nitrided in a low-pressure RF plasma," Surf. Coatings Technol., vol. 163-164, pp. 380-385, 2003.

[4] L. Mariano, S. Francisco, R. Perito, "Martensitic Stainless Steels Low-temperature Nitriding: Dependence of Substrate Composition 2," Experimental Procedure, vol. 18, pp. 622-627, 2015. 